\title{
Analisis Survival Pasien Hemodialisis dengan Hipertensi di Lampung Tahun 2016-2018
}

\author{
Survival Analysis of Hemodialysis Patients with Hypertension in Lampung Year 2016-2018 \\ Nurhalina Sari* dan Nova Muhani \\ Departemen Epidemiologi dan Biostatistik, Fakultas Kesehatan Masyarakat, Universitas Malahayati, Jln. Pramuka \\ No.27, Kemiling, Bandar Lampung, Lampung, Indonesia \\ *Korespondensi Penulis: nurhalinasari@gmail.com
}

Submitted: 13-09-2019, Revised: 02-05-2020, Accepted: 18-06-2020

DOI: https://doi.org/10.22435/mpk.v30i2.2251

\begin{abstract}
Abstrak
Penyakit ginjal kronis (PGK) saat ini menjadi masalah kesehatan serius dan jutaan meninggal setiap tahun karena tidak mempunyai akses untuk pengobatan. Salah faktor risiko utama penyakit katastropik ini adalah hipertensi. Tujuan penelitian untuk mengetahui angka ketahanan hidup pada kelompok hipertensi dan non hipertensi serta melihat hubungan antara tekanan darah, jenis kelamin, dan usia terhadap status kematian pasien PGK. Penelitian menggunakan desain studi kohort retrospektif. Data penelitian berasal dari rekam medis pasien di ruang hemodialisis Rumah Sakit Abdul Moeloek selama tahun 2016-2018 sebanyak 396 responden. Analisis data menggunakan Kaplan Meier dan regresi Cox. Hasil analisis menunjukkan kelompok hipertensi sebanyak $320(80,2 \%)$ dan non hipertensi sebanyak $76(19,8 \%)$ dengan proporsi kelompok hipertensi yang meninggal berjumlah 184 (57,5\%) orang. Ratarata ketahanan hidup kelompok hipertensi adalah 33 bulan, sedangkan pada kelompok non hipertensi adalah 44 bulan. Hasil uji log rank menunjukkan nilai $p$-value sebesar 0,007 yang menunjukkan perbedaan survival rate lebih rendah antara kelompok hipertensi dan non hipertensi. Hasil uji regresi Cox multivariat menunjukkan kelompok non hipertensi memiliki risiko ketahanan hidup 1,6 kali lebih lama dibandingkan dengan kelompok hipertensi ( $p$-value 0,006, 95\% Interval Kepercayaan 1,2-2,3) setelah dikontrol oleh jenis kelamin. Sedangkan variabel umur tidak berhubungan signifikan terhadap status kematian pasien PGK ( $p$-value 0,067). Kesimpulan adalah rata-rata lama hidup pasien PGK dari kelompok hipertensi lebih pendek dibandingkan kelompok non hipertensi. Kelompok hipertensi memiliki risiko ketahanan hidup lebih pendek dibandingkan kelompok non hipertensi terhadap pasien PGK yang menjalani hemodialisis. Selain itu, jenis kelamin perempuan memiliki risiko ketahanan hidup lebih lama setelah dikontrol oleh tekanan darah. Deteksi dini hipertensi sangat dianjurkan. Hal ini dapat dilakukan dengan mengontrol rutin tekanan darah dengan memanfaatkan program posbindu yang ada di puskemas. Selain itu, optimalisasi sosialisasi Gerakan Masyarakat Hidup Sehat (Germas) terutama untuk para remaja muda agar sadar tentang pentingnya kesehatan dan mengontrol tekanan darah rutin sejak usia berisiko 15 tahun.
\end{abstract}

Kata kunci: penyakit ginjal kronik (PGK); hemodialisis; hipertensi; analisis survival

\begin{abstract}
Chronic kidney disease (CKD) is now a serious health problem and millions die every year because they do not have access to treatment. One of the main risk factors for this catastrophic disease is hypertension. The purpose of this study was to determine survival rates in the hypertensive and non-
\end{abstract}


hypertensive groups and to see the relationship between blood pressure, sex and age on the death status of CKD patients. The study used a retrospective cohort study design. The research data came from the medical records of patients in the hemodialysis room of Abdul Moeloek Hospital during 2016-2018, was 396 respondents. Data analysis used Kaplan Meier and Cox Regression. The analysis showed the hypertensive groups were 320 (80.2\%) and non-hypertensive groups were 76 (19.8\%) with the proportion of hypertensive groups who died totaled 184 (57.5\%) people. The average survival rate of the hypertensive group was 33 months, whereas the non-hypertensive group was 44 months. The log rank test results showed a p-value of 0.007 which indicated a lower survival rate between the hypertensive and non-hypertensive groups. The results of the multivariate cox regression test showed that the nonhypertensive group had a 1.6 times longer survival risk compared to the hypertensive group ( $p$-value $0.006,95 \%$ Confident Interval 1.2-2.3) after being controlled by sex. While the age variable was not significantly related to the death status of CKD patients ( $p$-value 0.067). The conclusion is the average life span of CKD patients from the hypertensive group is shorter than the non-hypertensive group. The hypertensive group had a shorter survival risk than the non-hypertensive group of CKD patients undergoing hemodialysis. In addition, female sex has a risk of survival longer after being controlled by blood pressure. Early detection of hypertension is highly recommended. This can be done by controlling blood pressure routines by utilizing the postbindu program at the health center. In addition, optimizing Germas (community movement healthy life) socialization was especially for young teenagers to be aware of the importance of health and to control routine blood pressure since the age of 15 years at risk.

Keywords: chronick kidney disease (CKD), hemodialysis, hypertension, survival analysis

\section{PENDAHULUAN}

Penyakit ginjal kronis (PGK) di dunia saat ini mengalami peningkatan dan menjadi masalah kesehatan serius dan diperhitungkan. Hasil penelitian dari Global Burden of Disease pada tahun 2017 menyebutkan bahwa PGK merupakan penyebab kematian yang berada pada peringkat ke-27 di dunia pada tahun 1990 dan meningkat menjadi urutan ke-15 pada tahun 2017. ${ }^{1}$ Laporan yang sama menyebutkan juga bahwa lebih dari dua juta penduduk di dunia mendapatkan perawatan dengan dialisis atau transplantasi ginjal dan hanya sekitar $10 \%$ yang menjalani perawatan. Saat ini tercatat $10 \%$ penduduk di dunia mengalami PGK dan jutaan meninggal setiap tahun karena tidak mempunyai akses untuk pengobatan. Sejalan dengan data di atas, Kementerian Kesehatan melaporkan bahwa dari total populasi Indonesia yang berjumlah 258 juta jiwa, 73\% kematian yang terjadi di Indonesia disebabkan oleh penyakit tidak menular (PTM) dengan $27 \%$ diantaranya berisiko mengalami kematian dini. Salah satu penyumbang kematian dari PTM adalah PGK. ${ }^{2}$

Perkembangan PGK di Indonesia tercatat memiliki prevalensi sebesar $2 \%$ berdasarkan laporan Riset Kesehatan Dasar (Riskesdas) 2013. ${ }^{3}$ PGK ini menimbulkan beban biaya kesehatan tinggi hingga triliun rupiah. ${ }^{2}$ Perhimpunan Nefrologi Indonesia melaporkan bahwa pasien PGK yang melakukan hemodialisis tercatat hingga tahun 2016 sebanyak 25.446 pasien baru dan 52.835 pasien aktif. ${ }^{4}$ Faktor risiko penyakit ginjal kronik terbanyak adalah hipertensi dan diabetes melitus. ${ }^{4-7}$ Menurut laporan tahunan Indonesian Renal Registry (IRR), pada tahun 2015 tercatat PGK dengan penyakit penyerta hipertensi sebesar 50\% pada tahun 2016, kemudian naik menjadi 51\% dan stagnan hingga tahun 2018..$^{5-8}$ Pada laporan IRR terlihat PGK dengan hipertensi selalu menduduki peringkat pertama sebagai penyakit penyerta pasien. Beberapa penelitian menyebutkan bahwa terdapat hubungan hipertensi dengan kejadian PGK pada 
pasien yang menjalani hemodialisis. ${ }^{9-11}$ usia, riwayat hipertensi, diabetes melitus, frekuensi HD dan adanya komplikasi anemia. Analisis yang digunakan adalah uji Kaplan Meier dan Log Rank. Rata-rata ketahanan hidup pasien PGK dengan HD secara umum adalah 67,84 bulan. Pasien dengan jenis kelamin perempuan, pada rentang usia 46-65 tahun, frekuensi $\mathrm{HD} \geq 3$ kali, dan memiliki riwayat hipertensi, diabetes melitus serta adanya komplikasi anemia memiliki ratarata ketahanan hidup lebih rendah. Analisis uji Log Rank menunjukkan bahwa adanya perbedaan signifikan antar kategori dalam satu variabel bebas pada kurva survival ( $p$-value $<0,05$ ). Semakin lama menderita hipertensi maka risiko untuk PGK semakin besar. Faktor risiko utama yang akan diteliti adalah riwayat hipertensi dengan faktor pengganggunya adalah umur dan jenis kelamin. Peneliti tertarik untuk mengetahui lebih lanjut mengenai lama hidup dari pasien PGK yang telah menjalani hemodialisis dengan faktor risiko hipertensi.

Berdasarkan hal yang telah dikemukakan di atas, peneliti ingin mengetahui dan melakukan analisis lebih lanjut dengan studi kohort retrospektif mengenai ketahanan hidup pada pasien penyakit ginjal kronik yang menjalani hemodialisis dengan riwayat hipertensi di Rumah Sakit Abdul Moeloek, Lampung Tahun 2016 2018.

\section{METODE}

Penelitian ini menggunakan pendekatan desain studi kohort retrospektif. Populasi penelitian adalah pasien dengan status PGK yang menjalani hemodialisis di Rumah Sakit Abdul Moeloek pada 1 Januari 2016 hingga 31 Desember 2018. Besar sampel minimal dihitung menggunakan rumus uji survival dari Lwanga dan Lemeshow. ${ }^{12}$ Dengan derajat kemaknaan 95\% ( $\alpha=5 \%$ ), kekuatan $80 \%$ ( $\beta=20 \%)$, yang merujuk pada rasio hazard pasien PGK dengan riwayat hipertensi sebesar 3,02 dari penelitian Ding, et $a l,{ }^{13}$ maka besar sampel minimal yang dibutuhkan adalah 13. Pada penelitian ini sampel yang berhasil dikumpulkan sebanyak 396 pasien. ${ }^{14-16}$

Definisi PGK mengikuti panduan Kidney Disease Improving Global Outcome (KDIGO) 2012, yakni abnormalitas pada ginjal secara struktur atau fungsi selama lebih dari tiga bulan dengan implikasi pada kesehatan yang ditandai dengan salah satu dari tiga kondisi berikut: kelainan patologik/petanda kerusakan ginjal (kelainan darah, urin, atau pencitraan/imaging) atau e-LFG kurang dari $60 \mathrm{ml} / \mathrm{menit} / 1,73 \mathrm{~m}^{2}$ atau pasca transplantasi ginjal. ${ }^{17}$

Kriteria inklusi adalah pasien terdiagnosis utama PGK, usia $\geq 18$ tahun, mempunyai data riwayat menjalani hemodialisis, mempunyai hasil laboratorium fungsi ginjal (kreatin) pada awal menjalani hemodialisis, dan memiliki catatan tekanan darah. Variabel yang diukur dalam penelitian ini adalah tekanan darah yang dibagi menjadi non hipertensi (jika hasil ukur sistolik $<140 \mathrm{mmHg}$ dan diastolik $\leq 90 \mathrm{mmHg}$ ) dan hipertensi (jika hasil ukur sistolik $\geq 140$ $\mathrm{mmHg}$ dan diastolik $\geq 90 \mathrm{mmHg}$ ), jenis kelamin (perempuan dan laki-laki) dan umur pasien $(<50$ tahun dan $\geq 50$ tahun). Penelitian dilaksanakan di Rumah Sakit Abdul Moeloek selama satu tahun pengumpulan data sejak Oktober 2018 hingga Oktober 2019. Analisis data menggunakan uji survival, yaitu Kaplan Meier dengan Log Rank untuk melihat probabilitas ketahanan hidup pasien PGK, sedangkan Regresi Cox digunakan untuk mengestimasi rasio hazard (HR) dan 95\% confident interval (CI).

\section{HASIL}

\section{Karakteristik Pasien}

Pasien PGK didominasi oleh laki-laki sebanyak 56,6\%, mengalami hipertensi $80 \%$, dan meninggal 55,8\% (Tabel 1). Rata-rata usia pasien hemodialisis adalah 51 tahun dengan usia termuda 19 tahun dan tertua 82 tahun. Pasien hemodialisis ini rata-rata telah menjalani proses cuci darah selama 14 bulan dan pasien terlama selama 10,5 tahun/126 bulan. 
Tabel 1. Karakteristik Pasien

\begin{tabular}{lll}
\hline Variabel & Kategori & $\mathbf{n}(\mathbf{\%})$ \\
\hline Jenis kelamin & Perempuan & $172(43,4)$ \\
& Laki-laki & $224(56,6)$ \\
Usia & $<50$ tahun & $164(41,4)$ \\
& $\geq 50$ tahun & $232(58,6)$ \\
Status pasien & Hidup & $175(44,2)$ \\
& Meninggal & $221(55,8)$ \\
Tekanan darah & Nonhipertensi & $76(19,2)$ \\
& Hipertensi & $320(80,8)$ \\
\hline
\end{tabular}
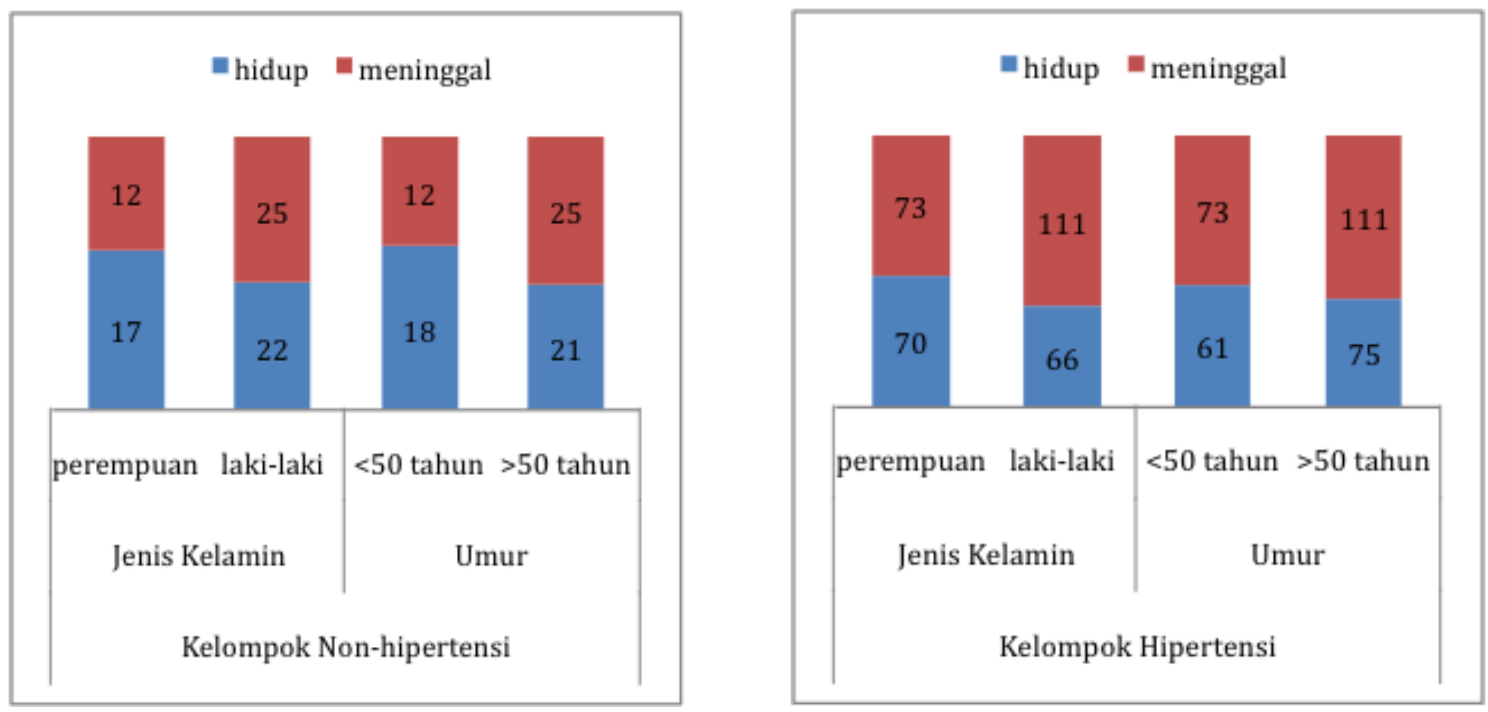

Gambar 1. Diagram Karakteristik Pasien

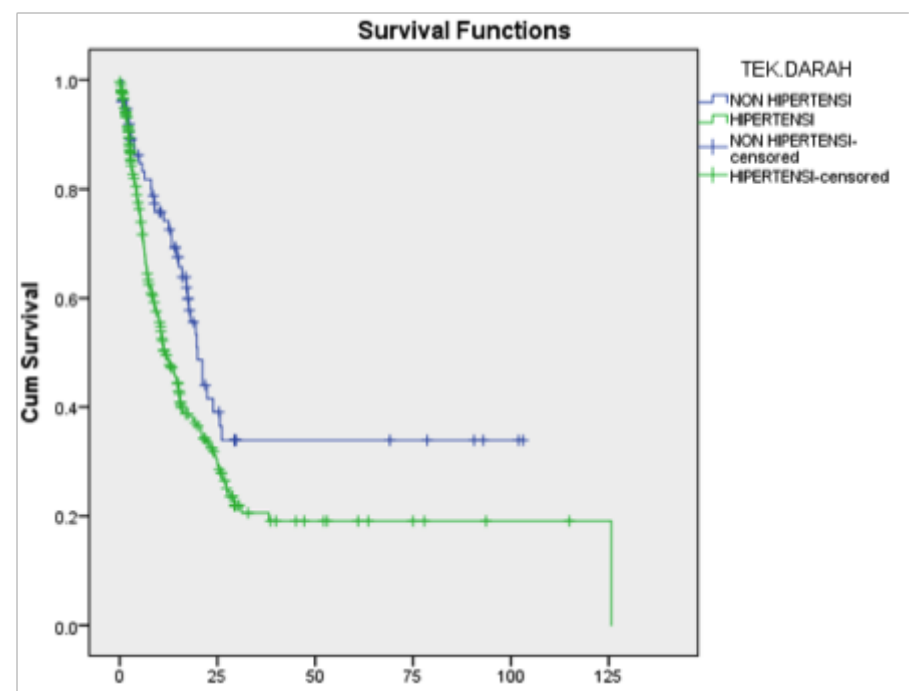

Gambar 2. Grafik Fungsi Survival Pasien Hemodialisis dengan Riwayat Hipertensi di RS Abdul Moeloek Tahun 2016-2018 
Tabel 2. Pemodelan Regresi Cox Survival Pasien Hemodialisis dengan Riwayat Hipertensi dan Variabel Lainnya

\begin{tabular}{lccc}
\hline Variabel & B & p-value & HR (95\%n IK) \\
\hline Tekanan Darah (hipertensi vs non hipertensi) & 0,5 & 0,006 & $1,6(1,2-2,3)$ \\
Jenis Kelamin (laki-laki vs perempuan) & 0,3 & 0,05 & $1,3(1,0-1,7)$ \\
\hline
\end{tabular}

*HR: Hazard Ratio, IK: Interval Kepercayaan

\section{Survival Pasien Hemodialisis dengan Riwayat Hipertensi}

Proporsi pasien hemodialisis yang memiliki riwayat hipertensi dan kemudian meninggal berjumlah $184(57,5 \%)$ orang. Pada grafik survival di atas (Gambar 2) terlihat ratarata ketahanan hidup kelompok hipertensi lebih rendah, yaitu 33 bulan dibandingkan dengan kelompok non hipertensi, yaitu 44 bulan. Hasil uji Log Rank (Mantel-Cox) dan omnibus test pada analisis regresi Cox menunjukkan nilai $p$-value sebesar $0,007(\alpha=5 \%)$, nilai ini secara statistik menunjukkan ada perbedaan survival rate antara kelompok hipertensi dengan non hipertensi.

\section{Survival Pasien Hemodialisis dengan Riwayat Hipertensi dan Variabel Lainnya}

Pada analisis menggunakan regresi Cox yang menghubungkan antara tekanan darah (non hipertensi dan hipertensi), jenis kelamin (perempuan dan laki-laki) dan umur $(<50$ tahun dan $\geq 50$ tahun) terhadap outcome status kematian pasien hemodialisis didapatkan kesimpulan bahwa hanya variabel tekanan darah dan jenis kelamin yang berhubungan (nilai $p$-value $\leq 0,05$ ). Hasil uji statistik diperoleh bahwa kelompok non hipertensi memiliki rasio ketahanan hidup 1,6 kali lebih tinggi pada IK 1,2-2,3 dibandingkan dengan kelompok hipertensi setelah dikontrol oleh jenis kelamin. Selanjutnya, kelompok perempuan memiliki rasio ketahanan hidup yang lebih tinggi 1,3 kali lebih tinggi pada IK 1,0-1,7 dibandingkan dengan kelompok laki-laki setelah dikontrol oleh tekanan darah.

\section{PEMBAHASAN}

PGK adalah penurunan progresif fungsi ginjal dalam beberapa bulan atau tahun. Penyakit ini didefinisikan sebagai kerusakan ginjal dan/ atau penurunan Glomerular Filtration Rate (GFR) kurang dari $60 \mathrm{~mL} / \mathrm{min} / 1,73 \mathrm{~m}^{2}$ selama minimal tiga bulan. ${ }^{14}$ Laporan terakhir yang dirilis oleh Indonesian Renal Registry (IRR) tahun 2018, ${ }^{8}$ diagnosis penyakit utama pasien hemodialisis di Indonesia berasal dari tiga jenis penyakit, yaitu: gagal ginjal akut (GGA) sebesar 8\%, gagal ginjal kronik (GGK/PGK) sebesar 90\%, dan GGA pada PGK sebesar 2\%. Adapun untuk penyakit penyertanya didominasi oleh hipertensi (51\%) dan diabetes melitus (21\%).

Pada penelitian ini didapatkan hasil bahwa kelompok hipertensi yang meninggal berjumlah 184 (57,5\%), artinya proporsi yang pasien meninggal karena hipertensi lebih besar dibandingkan non hipertensi. Faktor risiko penyakit ginjal kronis di Indonesia berdasarkan data Riset Kesehatan Dasar (Riskesdas) 2018 adalah hipertensi dengan prevalensi sebesar $25,8 \%$, obesitas $15,4 \%$ dan diabetes melitus 2,3\%. ${ }^{21}$ Beberapa laporan nasional menyebutkan penyebab kematian terbanyak pada pasien hemodialisis adalah kardiovaskuler dengan faktor risiko terbanyak adalah hipertensi. Hipertensi masih merupakan penyakit penyerta terbanyak, hal ini dapat diterangkan karena apapun penyakit dasar yang telah diderita oleh pasien, bila sudah mengalami PGK maka kontrol tekanan darah pun akan terganggu. ${ }^{2,3,5-8}$ Penelitian yang dilakukan oleh Nurcahyati ${ }^{19}$ dan Delima, et a ${ }^{20}$ menyebutkan bahwa terdapat hubungan antara tekanan darah dengan kualitas hidup pasien PGK dengan hemodialisis. Hasil yang sama dikemukakan didalam beberapa penelitian 
yang menyatakan bahwa pasien PGK yang menjalani hemodialisis yang memiliki riwayat hipertensi ketahanan hidupnya lebih rendah jika dibandingkan dengan yang tidak memiliki riwayat penyakit tersebut. ${ }^{9,21,22}$ Probabilitas ketahanan hidup pasien PGK yang menjalani hemodialisis dengan riwayat hipertensi makin lama akan semakin rendah. Hipertensi yang lama menyebabkan nefrosklerosis dan semakin lama menderita hipertensi, maka kerusakan glomerulus dan atrofi tubulus semakin parah sehingga menyebabkan seluruh nefron rusak dan berdampak pada gagal ginjal. ${ }^{9}$ Penyakit ginjal dapat menyebabkan naiknya tekanan darah dan sebaliknya hipertensi dalam jangka waktu lama dapat mengganggu ginjal. Pada penelitian ini sulit untuk membedakan kedua keadaan ini, karena keterbatasan data yang hanya bertumpu pada lembar rekam medis pasien. Beratnya pengaruh hipertensi pada ginjal bergantung dari tingginya tekanan darah dan lamanya menderita hipertensi. Makin tinggi tekanan darah dalam waktu lama maka makin berat komplikasi yang dapat ditimbulkan.

Sejalan dengan hasil penelitian dan laporan nasional IRR menyebutkan bahwa pasien hemodialisis didominasi oleh jenis kelamin lakilaki pada kisaran angka 56-60\%. Hasil analisis statistik didapatkan perempuan memiliki risiko ketahanan hidup lebih tinggi 1,3 kali dibandingkan laki-laki, atau dengan kata lain bahwa laki-laki lebih berisiko mengalami kematian lebih cepat, setelah dikontrol oleh variabel tekanan darah. Penelitian Sulistiowati dan Idaiani menyebutkan laki-laki memiliki risiko 2,97 kali lebih besar untuk mengalami PGK. ${ }^{23}$ Penelitian Pranandari dan Supadmi ${ }^{24}$ juga menyatakan hal sama bahwa laki-laki berisiko hingga 2 kali lebih tinggi untuk menderita PGK ( $p$-value $=0,04)$ dan beberapa penelitian lainnya. ${ }^{25}$ Namun dalam penelitian lain menunjukkan tidak ada hubungan antara jenis kelamin terhadap risiko ketahanan hidup pasien PGK. ${ }^{22}$ Perbedaan hasil penelitian ini disebabkan oleh beberapa faktor seperti pengaruh perbedaan hormon reproduksi; gaya hidup seperti konsumsi protein, garam, rokok dan konsumsi alkohol pada laki-laki dan perempuan.

\section{KESIMPULAN}

Rata-rata lama hidup pasien PGK dari kelompok hipertensi lebih pendek dibandingkan kelompok non hipertensi. Kelompok hipertensi memiliki risiko ketahanan hidup lebih pendek dibandingkan kelompok non hipertensi terhadap pasien PGK yang menjalani hemodialisis. Selain itu, jenis kelamin perempuan memiliki risiko ketahanan hidup lebih lama setelah dikontrol oleh tekanan darah.

\section{SARAN}

Hipertensi adalah penyakit yang tidak diketahui penyebabnya, tidak dapat dicegah tetapi dapat dikontrol agar kondisinya tidak bertambah parah. Deteksi dini hipertensi sangat dianjurkan. Hal ini dapat dilakukan dengan mengontrol rutin tekanan darah melalui tenaga kesehatan dengan memanfaatkan program posbindu yang ada di puskemas. Selain itu, optimalisasi sosialisasi Gerakan Masyarakat Hidup Sehat (Germas) terutama untuk para remaja muda agar sadar tentang pentingnya kesehatan dan mengontrol tekanan darah rutin sejak usia berisiko 15 tahun. Bagi mereka yang telah terdiagnosis positif mengalami hipertensi juga disarankan untuk patuh mengonsumsi obat antihipertensi agar tekanan darahnya terkontrol dan berupaya mengubah gaya hidup serta mengendalikan stres. Penelitian lanjutan perlu dilakukan dengan menggunakan data pasien yang lebih akurat terkait status lamanya dan terkontrol tidaknya hipertensi pasien dan faktor penting lainnya seperti gula darah/diabetes.

\section{UCAPAN TERIMA KASIH}

Ucapan terima kasih kepada pihak Rumah Sakit Abdul Moeloek yang telah memberi kesempatan peneliti untuk melakukan penelitian. Peneliti juga mengucapkan terimakasih banyak atas kontribusi Direktorat Jenderal Penguatan Riset dan Pengembangan, Kementerian Riset, Teknologi dan Pendidikan Tinggi Republik Indonesia sebagai penyandang dana penelitian dan LPPM Universitas Malahayati yang selalu mendukung kegiatan penelitian di lingkungan universitas. 


\section{DAFTAR PUSTAKA}

1. Stanaway JD, Afshin A, Gakidou E, Lim SS, Abate D, Abate KH, et al. Global, Regional, and National Comparative Risk Assessment of 84 Behavioural, Environmental and Occupational, and Metabolic Risks or Clusters of Risks for 195 Countries and Territories, 1990-2017: A Systematic Analysis for the Global Burden of Disease Study 2017. Lancet. 2018;392(10159):1923-94.

2. Moeloek NF. Air Bagi Kesehatan: Upaya Peningkatan Promotif Preventif bagi Kesehatan Ginjal di Indonesia [Internet]. Jakarta; 2018 [cited 2018 Aug 31]. Available from: https://www.persi. or.id/images/2018/data/materi_menkes.pdf

3. Badan Penelitian dan Pengembangan Kesehatan. Riset Kesehatan Dasar (RISKESDAS) 2013, Laporan Nasional 2013. Jakarta : Badan Penelitian dan Pengembangan Kesehatan; 2013.

4. Lydia A, Nugroho P. Kondisi Kesehatan Ginjal Masyarakat Indonesia dan Perkembangannya [Internet]. 2018 [cited 2018 Aug 31]. Available from: https://www.persi.or.id/images/2018/data/ aida_lydia.pdf

5. Indonesian Renal Registry Team. 8 th Report of Indonesian Renal Registry 2015 [Internet]. 2015 [cited 2018 Aug 30]. Available from: https://www. indonesianrenalregistry.org/data/INDONESIAN RENAL REGISTRY 2015.pdf

6. Indonesia Renal Registry Team. 9 th Report of Indonesian Renal Registry 2016 [Internet]. 2016 [cited 2018 Aug 31]. Available from: https://www. indonesianrenalregistry.org/data/INDONESIAN RENAL REGISTRY 2016.pdf

7. Indonesian Renal Registry Team. 10 th Report of Indonesian Renal Registry 2017 [Internet]. 2017. Available from: https://www. indonesianrenalregistry.org/data/IRR 2017 .pdf

8. Indonesian Renal Registry Team. 11 th Report of Indonesian Renal Registry 2018 [Internet]. 2018. Available from: https://www. indonesianrenalregistry.org/data/IRR 2018.pdf

9. Yulianto D, Basuki H, Widodo. Analisis Ketahanan Hidup Pasien Penyakit Ginjal Kronis dengan Hemodialisis di RSUD Dr. Soetomo Surabaya. J Manaj Kesehat Yayasan RSDr Soetomo [Internet]. 2017;3(1):96. Available from: https://media. neliti.com/media/publications/258424-analisisketahanan-hidup-pasien-penyakit-a82c8244.pdf

10. Hidayati T, Kushadiwijaya H, Suhardi. Hubungan antara Hipertensi, Merokok dan Minuman Suplemen Energi dan Kejadian Penyakit Ginjal Kronik. Ber Kedokt Masy [Internet]. 2008;24(2):90-102. Available from: https:// journal.ugm.ac.id/bkm/article/view/3600

11. Fitrianto H, Azmi S, Kadri H. Penggunaan Obat Antihipertensi pada Pasien Hipertensi Esensial di Poliklinik Ginjal Hipertensi RSUP DR. M. Djamil Tahun 2011. J Kesehat Andalas [Internet]. 2014;3(1):45-8. Available from: Penggunaan Obat Antihipertensi pada Pasien Hipertensi Esensial di Poliklinik Ginjal Hipertensi RSUP DR. M. Djamil Tahun 2011

12. Ogston SA, Lemeshow S, Hosmer DW, Klar J, Lwanga SK. Adequacy of Sample Size in Health Studies. Biometrics. 1991;47(1):347.

13. Ding C, Yang Z, Wang S, Sun F, Zhan S. The Associations of Metabolic Syndrome with Incident Hypertension, Type 2 Diabetes Mellitus and Chronic Kidney Disease: a Cohort Study. Endocrine [Internet]. 2018;60(2):282-91. Available from: http://dx.doi.org/10.1007/ s12020-018-1552-1

14. Ruang Hemodialisa RSUD Dr. H. Abdul Muluk. Laporan Bulanan Frekuensi Tindakan Hemodialisa Tahun 2016. Bandar Lampung : RSUD Dr. H. Abdul Muluk; 2016.

15. Ruang Hemodialisa RSUD Dr. H. Abdul Muluk. Laporan Bulanan Frekuensi Tindakan Hemodialisa Tahun 2017. Bandar Lampung : RSUD Dr. H. Abdul Muluk; 2017.

16. Ruang Hemodialisa RSUD Dr. H. Abdul Muluk. Laporan Bulanan Frekuensi Tindakan Hemodialisa Tahun 2018. Bandar Lampung : RSUD Dr. H. Abdul Muluk; 2018.

17. KDIGO. KDIGO 2012 Clinical Practice Guideline for the Evaluation and Management of Chronic Kidney Disease. Kidney Int Suppl [Internet]. 2013 [cited 2018 Sep 1];3(1):1-150. Available from: http://www.kidney-international.org

18. Badan Penelitian dan Pengembangan Kesehatan. Hasil Utama Riskesdas 2018. Jakarta : Kementerian Kesehatan; 2018. 
19. Nurcahyati S. Faktor-Faktor yang Berhubungan dengan Kualitas Hidup Pasien Hemodialisis di Rumah Sakit Islam Fatimah Cilacap dan Rumah Sakit Umum Daerah Banyumas [Internet]. Indonesia; 2011. Available from: http:/lib. ui.ac.id/file?file=digital/20282431-T Sofiana Nurchayati.pdf

20. Delima D, Tjitra E, Tana L, Halim FS, Ghani L, Siswoyo H, et al. Faktor Risiko Penyakit Ginjal Kronik : Studi Kasus Kontrol di Empat Rumah Sakit di Jakarta Tahun 2014. Bul Penelit Kesehat [Internet]. 2017;45(1):17-26. Available from: http://ejournal.litbang.kemkes.go.id/index.php/ BPK/article/download/7328/5123

21. Pongsibidang GS. Risk Factor Hypertension, Diabetes and Consuming Herbal Medicine of Chronic Kidney Disease In Dr. Wahidin Sudirohusodo Hospitals Makassar 2015. J Wiyata [Internet]. 2016;3(2):162-7. Available from: https://ojs.iik.ac.id/index.php/wiyata/article/ view $/ 87$

22. Ebad M. Survival analysis of chronic dialysis patients [Internet]. University of Waterloo; 2018 [cited 2018 Aug 31]. Available from: http://hdl. handle.net/10012/13584

23. Sulistiowati E, Idaiani S. Risk Factors of Chronic Kidney Disease Based on CrossSectional Analysis Baseline Cohort Study Non-
Communicable Diseases at Population 25-65 Years Old in Kebon Kelapa, Bogor 2011. Bul Penelit Kesehat [Internet]. 2015;43(3):163-72. Available from: http://ejournal.litbang.kemkes. go.id/index.php/BPK/article/view/4344/4000

24. Pranandari R, Supadmi W. Risk Factors Cronic Renal Failure on Hemodialysis Unit in RSUD Wates Kulon Progo. Maj Farm [Internet]. 2015;22(2):316-20. Available from: https:// jurnal.ugm.ac.id/majalahfarmaseutik/article/ view/24120/15776

25. Chang PY, Chien LN, Lin YF, Wu MS, Chiu WT, Chiou HY. Risk Factors of Gender for Renal Progression in Patients with Early Chronic Kidney Disease. Med (United States) [Internet]. 2016;95(30). Available from: https://journals. lww.com/md-journal/fulltext/2016/07260/risk factors_of_gender_for_renal_progression_in.26. aspx 